\title{
Analysis of Indonesia Banking Structure
}

\author{
Puti Sinansari $^{1}$, DS Priyarsono ${ }^{2}$, Gendut Suprayitno $^{3}$ \\ ${ }^{1}$ School of Business, Bogor Agricultural University (IPB), J1. Raya Pajajaran Bogor Indonesia16151, Indonesia \\ ${ }^{2}$ School of Business, Bogor Agricultural University (IPB), J1. Raya Pajajaran Bogor Indonesia16151, Indonesia \\ ${ }^{3}$ School of Business, Bogor Agricultural University (IPB), Jl. Raya Pajajaran Bogor Indonesia16151, Indonesia
}

\begin{abstract}
The growing number of banks in Indonesia is increasing along with the globalization that causes the level of competition in the banking industry is getting tighter. Fierce competition requires banks to improve their performance in a healthy and solid. Banking health alone is not enough to define in detail the state of the bank, so an approach is needed through the industrial organization model using structural, behavioral, and performance instruments. This study will be more detailed in discussing the banking structure by using a sample of 78 banks in Indonesia processed through panel data from 2008 to 2015. The result is that the Indonesian banking competition is in the oligopoly area which is currently controlled by two large institutions namely Bank Indonesia and the Service Authority Finance.
\end{abstract}

Keywords: banking industry, banking structure, market structure

\section{Introduction}

The contribution of Indonesia's financial sector to Gross Domestic Product (GDP) from 2008 to 2015 only ranges from $3 \%-4 \%$, this amount is considered too small for the size of the country as big as Indonesia because there are more than $64 \%$ of the business sector that has not been touched or served by the financial services own (Sari 2016).

As one of the largest country in ASEAN, Indonesia has the largest net interest margin (NIM) and indicates that banks in Indonesia have better efficiency than other ASEAN countries. However, the role of the financial sector still contributes little to Indonesia's economic growth.

The banking industry has certain characteristics that are very different from other industries, so it needs distinct regulations and laws to be able to regulate this industry in order to run in accordance with its main objective to a healthy banking. Overcompetition in the banking industry will force banks to take higher risks, especially in credit market competition (Ariyanto 2004).

The regulation of the Indonesian banking structure is regulated by Bank Indonesia (BI) through the Indonesian Banking Architecture (API), which is a basic framework for the development of a comprehensive Indonesian banking system for the next five to ten years. This concept is constantly updated to follow the dynamism of the banking industry. API is expected to provide the direction, form and structure of the banking industry. The purpose of API is to create a sound, strong and efficient banking industry, create financial system stability and promote national economic growth (Bank Indonesia 2010).

Indonesia banks consists of private banks, state-owned banks, regional banks and others. The existence of this bank certainly affects the condition of Indonesian banking, especially since the existence of the policy of Bank Indonesia (BI) to separate the microprudential policy which finally held by the Financial Services Authority (OJK). The structure of the Indonesian banking system does not change completely but the impact of this policy and the financial crisis that struck Indonesia from 2008 - 2015 certainly has an influence on the Indonesian banking structure.

In order to know the condition of banking Indonesia needed an instrument to analyze it. One of the instruments that can be used is the industrial organization model that named structure, conduct and performance (SCP). Even though SCP analyze an industry from three compenents but in this research it will only discuss about the structure, especially Indonesian banking structure.

Sahoo and Mishra (2013) argue that there is a significant relationship to the intensity of sales, assets, performance and market size. The existence of a relationship between an asset and a market size due to competitive competition with large assets and market size will support the structure of a banking industry. This research will discuss about the influence of assets, sales intensity, performance results on the amount of assets used (return on assets / ROA) and market size. The purpose of this study is to analyze the structure of Indonesian banking and identify the variables that influence it. In addition, this research would like to see the form of Indonesian banking structure and analyze it for the future.

\section{Literature Review}

The market structure is the classification of producers to some form of market based on characteristics such as the type of product produced, the number of companies in the industry, the entry barrier of industry and the role of marketing in industrial activities (Mayasari 2012). The market structure is a relatively permanent strategic element of the corporate environment that affects and is influenced by behavior and performance in the market (Koch 2001).

Market structure is an aggregation of every business actor in the industry, in this research is the banking industry. Measurement of aggregation is measured through market share owned by each bank. Market share is known through 


\section{International Journal of Science and Research (IJSR) \\ ISSN (Online): 2319-7064 \\ Index Copernicus Value (2015): 78.96 | Impact Factor (2015): 6.391}

the amount of third party funds (TPF) of each bank compared to the central bank's TPF. TPF consists of demand deposits, savings deposits and deposits that have been able to represent the reach of a market owned by a bank. In addition, this study also calculates the market concentration index using the Herfindahl-Hirschman Index (HHI) to see the level of banking industry competition (Sutardjo et al 2011)

\section{Methods}

\subsection{Types and Sources of Data}

The data used in this study is secondary data taken from the annual report of the active Indonesia Bank from 2008 to 2015 amounted to 78 banks. Data taken from the bank's annual report are asset, branch office growth, return on asset (ROA), and total sales of each bank or credit offered. All of this data is taken in the timeframe of 2008 to 2015.

\subsection{Methodology}

According to Firdaus (2011), the approach with panel data is done by looking at the behavior of various individuals (cross section) on a set time (time series). Panel data conducted in this study is to see the effect of some predetermined variables on the structure of the Indonesian banking industry within the period 2008 to 2015. Panel data regression analysis has three models: (1) Common Effect Model; (2) Fixed Effect Model (FEM), (3) Random Effect Model (REM).

The advantage of the panel data method are, the panel data regression method uses two kinds of data ie time series and cross section so that will reduce the bias in regression calculation. Furthermore, panel data methods can reduce the shortcomings of time series and cross section.

$$
\begin{gathered}
\text { SHARE }_{i t}=\mathrm{f} 1\left(\mathrm{ASET}_{\mathrm{it}}, \mathrm{SELL}_{\mathrm{i}, \mathrm{t}-1}, \mathrm{ROA}_{\mathrm{i}, \mathrm{t}-1}, \mathrm{SIZE}_{\mathrm{it},}\right) \\
\text { SHARE }_{\mathrm{it}}=\alpha+\beta_{1} \mathrm{ASET}_{\mathrm{it}}+\beta_{2} \text { SIZE }_{\mathrm{i}, \mathrm{t}-1}+\beta_{3} \mathrm{SELL}_{\mathrm{i}, \mathrm{t}-1} \\
+\beta_{4} \mathrm{ROA}_{\mathrm{i}, \mathrm{t}-1}+\varepsilon_{\mathrm{it}}
\end{gathered}
$$

di mana:

SHARE $_{\text {it }}$

ASET $_{\text {it }}$

SELL $_{i, t-1}$

: Market Share

$\mathrm{ROA}_{\mathrm{i}, \mathrm{t}-1}$

: Bank Asset

$\mathrm{SIZE}_{\text {it }}$

: Selling Intensity

: Bank Performance

: Market Size

\section{Result}

Based on observations made on the real level of 0.05 , it is seen that ASET, SELL and ROA positively significant influence on the value of SHARE. While the value of SIZE has positive but not significant effect on SHARE value because its probability is at 0.0502 , exceed or equal to the specified real level.

ASET variable is the amount of assets owned by a bank affecting the Indonesian banking industry, this study shows that the assets have a significant positive influence on SHARE which is indicated by the probability value of 0.00 . Coefficient value $2.20 \times 10^{-5}$ shows that every $1 \%$ increase of
SHARE variable will affect $2.20 \times 10^{-5} \%$ against variable ASET.

SELL shows the intensity of sales of bank products that have a significant positive influence on the SHARE variable, indicated by the probability value of 0.00 . The coefficient value of $4.36 \times 10^{-4}$ shows that every $1 \%$ increase of SHARE variable will affect $4.36 \times 10^{-4} \%$ against SELL variable.

ROA shows the performance of the banking industry has a probability of 0.0146 which means that this variable has a significant influence on SHARE.

ROA shows the performance of the banking industry has a probability of 0.0146 which means that this variable has a significant influence on SHARE. The coefficient value $9.39 \times 10^{-5}$ shows that the relationship ROA with SHARE inversely proportional which means every $1 \%$ increase SHARE variable will decrease ROA as much as $-9.39 \times 10$ ${ }^{5} \%$.

SIZE is a market size variable measured by how many sales are performed by a bank, this variable has a probability value of 0.05 which indicates that this variable has no significant effect on SHARE because above the real level of 0.05 .

Previous research by Sutardjo (2011), Sahoo and Mishra (2012) and Puspasari (2013) have examined the structure of a banking industry.

Table 1: Estimation of Structural Model

\begin{tabular}{|c|c|c|c|c|}
\hline Variable & Coefficient & Std. Error & $t$-Statistic & Prob. \\
\hline ASET & $2.20 \times 10^{-5}$ & $2.58 \times 10^{-6}$ & $8.52 \times 10^{6}$ & $\mathbf{0 . 0 0 0 0}$ \\
\hline SELL & $4.36 \times 10^{-4}$ & $1.49 \times 10^{-5}$ & $29.14 \times 10^{5}$ & $\mathbf{0 . 0 0 0 0}$ \\
\hline ROA & $-9.39 \times 10^{-5}$ & $3.83 \times 10^{-5}$ & $-2.45 \times 10^{6}$ & $\mathbf{0 . 0 1 4 6}$ \\
\hline SIZE & $3.44 \times 10^{-5}$ & $1.75 \times 10^{-5}$ & $1.75 \times 10^{-5}$ & 0.0502 \\
\hline C1 & $-5.19 \times 10^{-3}$ & $5.12 \times 10^{-4}$ & $-2.96 \times 10^{6}$ & 0.0032 \\
\hline r-squared & 0.993914 & & & \\
\hline Adjusted r-squared & 0.992598 & & & \\
\hline
\end{tabular}

These three studies explain that ASET plays an important role in the banking structure. However, the difference of this research with previous research is SIZE variable (market size) which have insignificant influence on the real level of 0.05. This could be due to the economic slowdown in Indonesia which has an impact on the reduction of credit offered.

\subsection{Market Concentration Analysts}

Measurement of market concentration by using herfindahlhirschman index (HHI) is 743.24, referring to the United States Antitrust Department of Justice Division and Federal Trade Commission in Horizontal Merger Guideliness and Gwin (2000) this value belongs to the category of concentrated industry. This means that the banking industry is dominated by large banks that control most of the existing market share. According to Nugroho (2014), the stability of the market concentration value indicates that during the last eight years market share is controlled by only a few business actors. According to Nugroho (2014), the stability of the market concentration value indicates that during the last

\section{Volume 6 Issue 7, July 2017 www.ijsr.net}




\section{International Journal of Science and Research (IJSR) \\ ISSN (Online): 2319-7064}

Index Copernicus Value (2015): 78.96 | Impact Factor (2015): 6.391

eight years market share is controlled by only a few business actors. The impact of this market concentration value is the oligopoly industry structure which facilitates new bank companies with sufficient strength to compete competitively in fighting for the market share of Indonesian banks

Table 2: HHI Index of Indonesia Banking Industry

\begin{tabular}{|c|c|}
\hline Year & HHI \\
\hline 2008 & 715.13 \\
\hline 2009 & 749.92 \\
\hline 2010 & 738.23 \\
\hline 2011 & 729.76 \\
\hline 2012 & 725.19 \\
\hline 2013 & 818.72 \\
\hline 2014 & 745.46 \\
\hline 2015 & 723.54 \\
\hline Average & 743.24 \\
\hline
\end{tabular}

Based on the measurement of HHI index, the state of Indonesian banking market is in oligopoly competition, where the number of business actors is quite high and the control of the market is also considered quite strong.

This is very good considering the two major institutions that govern the Indonesian banking Bank Indonesia (BI) and the Financial Services Authority (OJK) has been working hard to strengthen the Indonesian banking industry amid the onslaught of world crisis in recent years. The number of large business actors also has a downward trend from year to year, several small banks merged together to collect larger assets (Baskoro 2014).

Concentration is an indicator that is often used to know the market structure. Concentration is defined as the ownership or control of a large number of economic resources by a small number of economic units. By knowing the level of concentration on an industry can be determined the market structure. The concentration level measurement can also be used to determine the concentration of resource ownership in a market or economy as a whole (Ririhena 2013).

Market concentration can be seen as a whole based on the differences in the number of companies in the market, the relative reach of each company and the control of the market. Perfect competition lies at one end and a monopoly on the other. The essence of this continuum is that monopolistic competition combines with oligopoly, there is no clear line separating it so that market conditions may change from time to time.

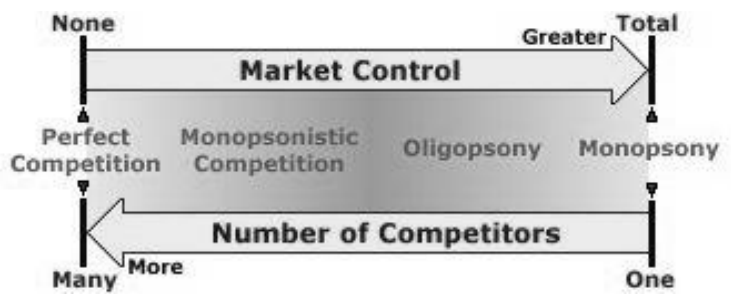

Figure 1: Market Structure Continuum

The more to the left then the barriers to entry will be easier and more and more business players are playing in the market. Indonesia's banking industry is in oligopoly market conditions. From the producers or industry players, it is advantageous because the competitors in quantity are still relatively small but the strength is quite large because it has substantial market control. While from the consumer side, the situation is almost the same as the industry players that consumers also have substantial market control.

Sutardjo (2011) conducted research on the banking structure from 1999-2009 argued that the competition of Indonesian banking is in monopolistic competition and rests on the competition of interest. In this research, however, Indonesian banking competition has shifted towards oligopoly. Oligopoly itself is a market condition in which new competitors will be hard to enter because of high capital intensive and there is a regulator that controls this.

Characteristics of oligopoly competition are not too many players in the industry, homogeneous or differentiated products, profit-taking interacts with each other, competition is non-price competition. Competition in this oligopoly will give the benefit to the consumer to choose a bank that suits their needs, besides from the side of their own banking they can do research and product development to increase consumer satisfaction because competition is happening is non-price competition but the quality of service given at consumer.

\subsection{Analysis of Indonesian Financial Market Structure}

The root of the problem of policy effectiveness lies in two things namely, the structure of financial markets and the credibility of BI. First, the structure of financial markets. The structure of our financial markets is still very underdeveloped, shallow and very bank-centric. Most financial transactions still rely heavily on the role of banks, while other financial sector such as capital markets, pension funds, insurance, is still very small role for Indonesia's financial sector. The bank has a very high bargaining power. In addition, our banking structure is also inefficient, in addition to too many banks, the structure of third party funds are also only concentrated by multiple accounts.

Banking structure in Indonesia is influenced by two things: monetary policy and banking institution policy. These two policies are held by two different regulators. The monetary policy is regulated by BI called Inflation Targetting Framework (ITF) which has been implemented since July 2005. The ITF is an inflation-based monetary policy, each $\mathrm{BI}$ period will evaluate whether future inflation projections are still in line with the set targets. This projection is carried out with a number of models and some information that can illustrate future inflationary conditions. Jika proyeksi inflasi sudah tidak kompatibel dengan sasaran maka BI akan melakukan respon dengan menggunakan instrumen yang dimiliki (Bank Indonesia 2010).

While the policy of banking institutions starting in 2013 has been done by OJK. Arrangement and supervision on institutional, health, prudential aspects, and bank checks are the scope of microprudential regulation and control which is the duty and authority of OJK. The purpose of microprudential surveillance is to maintain the financial level of individual financial institutions. The principles of

\section{Volume 6 Issue 7, July 2017 www.ijsr.net}




\section{International Journal of Science and Research (IJSR) \\ ISSN (Online): 2319-7064 \\ Index Copernicus Value (2015): 78.96 | Impact Factor (2015): 6.391}

capitalization, asset quality, profitability and liquidity management and risk sensitivity (Financial Service Authority 2010)

Currently the Indonesian banking industry is controlled by the two highest institutions that BI for macroprudential policy and the FSA for mikroprudensial policy. These two regulators are good banking handling systems, both internal and external. External or policy outside the bank has been regulated by BI so that the banking industry itself is comfortable doing business amid the onslaught of the world economy. While from the internal side itself, the banking industry players are guaranteed by OJK that serves to regulate, supervise and protect individual banks to fit the existing rules.

\section{Conclusion}

The structure of Indonesian banking is classified as an oligopoly structure controlled by several large banks. While the factors that affect the structure is the asset, the intensity of panjualan and performance. The oligopoly banking structure influences the banking behavior by establishing many branch offices so as to have more power in reaching the market. Indonesia's banking system is good but still must be addressed and can no longer depend on DPK alone. Investment from the public should be increased so that the bank's capital is increasingly liquid and strong in facing various future

\section{References}

[1] Bank Indonesia. 2009. Outlook ekonomi Indonesia 2009 - 2014: krisis finansial global dan dampaknya terhadap perekonomian Indonesia. Jakarta (ID): Bank Indonesia.

[2] Ariyanto T. 2004. Profit Persaingan Usaha Dalam Industri Perbankan Indonesoa. Komisi Pengawas Persaingan Usaha (KPPU): Jakarta

[3] Baskoro H. 2014. Faktor-faktor yang mempengaruhi tingkat pengungkapan risiko perusahaan pada industri perbankan Indonesia. [tesis] Jakarta (ID): Indonesia Banking School.

[4] Firdaus M. Aplikasi Ekonometrika untuk Data Panel dan Time Series. Departemen Ilmu Ekonomi. FEM IPB: Bogor(ID)

[5] Koch R. 2001. Guide to Strategy: How to Create and Deliver a Useful Strategy. $2^{\text {nd }}$ Ed. London (GB): Prentice-Hall

[6] Mayasari L. 2012. Analisis Pengaruh Kebijakan Arsitektur Perbankan Indonesia (API) terhadap Struktur, Perilaku dan Kinerja Industri Perbankan Indonesia. Tesis. Universitas Indonesia

[7] Nugroho AA. 2014. Analisis industri perbankan Indonesia tahun 2009 - 2012 dengan pendekatan structure conduct and performance [tesis]. Semarang (ID): Universitas Diponegoro

[8] Puspasari A. 2013. Pengaruh struktur pasar terhadap profitabilitas industri perbankan Indonesia [tesis]. Yogyakarta (ID): Universitas Gadjah Mada.
[9] Ririhena VA. 2013. Analisis Konsentrasi Pasar Sepeda Motor di Yogyakarta Tahun 2003-2010. Jurnal Universitas Atma Jaya Yogyakarta.

[10] Sahoo D, Mishra P. 2012. Structure, conduct and performance of indian banking sector. Journal Review of Economic Perspective. 12(4): 235 - 264

[11] Sari, EV. 2016. Kontribusi sektor keuangan terhadap ekonomi masih minim [internet]. [diakses pada 2016 $\begin{array}{lll}\text { Agustus } & 20] \text {. Terdapat pada }\end{array}$ http://www.cnnindonesia.com/ekonomi/2016050913151 3-78-129407/kontribusi-sektor-keuangan-terhadapekonomi-masih-mini/

[12] Sutardjo, Priyarsono DS, Hartoyo S. 2011. Struktur Pasar Persaingan Perbankan Indonesia Dalam Periode Konsolidasi. Jurnal Manajemen dan Agribisnis. 8(2):40-52

[13] Rizaldi AF. 2000. Analisis kinerja dan strategi investasi kelompok saham sektor agribisnis di bursa efek Jakarta (studi kasus periode pra krisis - krisis - pemulihan) [tesis]. Bogor (ID): Institut Pertanian Bogor.

[14] Purnamawati DA. 2011. Analisis tingkat kesehatan bank XYZ [tesis]. Bogor (ID): Institut Pertanian Bogor.

[15] Sealey C, Lindley J. 1977. Inputs, outputs and a theory of production and cost at depository financial institutions. The Journal of Finance. 32(4): 1251 - 1266

[16] Seelanatha L. 2010. Market structure, efficiency and performance of banking industry in Sri Lanka. Journal of Banks and Bank Systems. 5(1): 30-45.

[17] Sitompul M. 2014. Pengaruh financial distress dengan menggunakan altman z-score, beta saham, dan inflasi terhadap return saham perusahaan manufaktur yang terdaftar di BEI tahun 2008-2012 [tesis]. Bandung (ID): Universitas Kristen Maranatha

[18] Sitorus RE. 2008. Economies of scale, economies of scope dan technical change bank-bank umum swasta devisa besar di Indonesia [disertasi] Yogyakarta (ID): Universitas Gadjah Mada.

[19] Situmorang, DP. 2016. Pengaruh faktor internal terhadap kemampulabaan industri perbankan di bursa efek Indonesia [tesis] Medan (ID): Universitas Sumatera Utara.

[20] Smith A. 1776. The Wealth of Nations. London (GB): W. Strahan and T. Cadell. 